\title{
ITSEOHJAUTUVUUS AIKUISKOULUTUKSESSA
}

\author{
Heikki Pasanen
}

\begin{abstract}
Itseohjautuvuus opiskelussa ja oppimisessa on liitetty aikuisuuteen. Jukka Koro on todennut jokaisen aikuisen olevan itseohjautuvan ja tekevän matkaansa kohti omaa itseään ja täydellistymistään. Itseohjautuvuuden ei kuitenkaan pidä merkitä yksinopiskelua tai aikuisen jättämistä opintoineen yksin. Oppimisella on mitä selkeimmin yhteistoiminnallinen luonne. "Ihmisen älykäs toiminta sijaitsee, jos sille jokin paikka halutaan osoittaa, pikemminkin ihmisten välisissä toiminnoissa kuin yksilön päässä”, Heikki Pasanen kirjoittaa.
\end{abstract}

\begin{abstract}
Tseohjautuvuus on liitetty yksilön itsemäärääImiseen, vastuuseen, autonomiaan, yksilön minäkäsitykseen. Itseohjautuvuus tuntuu siten olevan länsimaisten yksilöllisyyttä korostavien arvojen ja ihanteiden mukainen ominaisuus. Etenkin yhteiskunnissa, joissa yksittäistä "yksilöä" korostetaan, nousevat yksilön ominaisuudet luontevasti esille kategoriana, jolla loppujen lopuksi kaikki selitetään, kun muut selitykset loppuvat. Millainen onkaan tilanne esimerkiksi Japanissa, jossa spesifiä minän käsitettä ei sisälly kieleen? Kuka sitten ohjaa itseä, ellen minä itse?
\end{abstract}

Itseohjautuvuus on erityisesti sellaisen psykologiatieteen herkkupala, jolla on haluttu nostaa yksilöä keskeiseen rooliin suhteessa sosiaalisiin konstruktioihin sekä tieteessä teoreettisesti että käytännön toimijana. Kun toisaalla esimerkiksi itsemäärääminen ja autonomian hyväksyminen ovat varmistamassa ja turvaamassa yksilön koskemattomuuden ja suvereenisuuden toimijana, ajattelijana, kansalaisena, opiskelijana, on vastuun käsite varmistamassa sitä, että juuri minä itse olen vastuussa itsestäni. Jos en tule omilla eväilläni toimeen, sitten en mahdollisesti ole myöskään riittävän itseohjautuva, mutta en voi muiltakaan vaatia itselleni autonomian takaamista. Arkikäsitteenä itseohjautuvuudella ja autonomialla on voimakas miellemerkitys juuri yksilön itsenäisyyteen ja siihen että hän yksin on vastuussa sekä hyvässä että pahassa siitä, mitä hänelle toiminnoissaan käy.

$\mathrm{D}$ avid Riesmanin sosiologinen tutkimus Lonely Crowd jakoi amerikkalaiset miehet ulkoa ohjautuviksi ja sisältä ohjautuviksi. Riesmanin mukaan ennen I maailmansotaa tyypillinen amerikkalainen oli "sisältä ohjautuva" ja varustettu (psykoanalyyttisesti) vahvalla superegolla. Varma ja itsellinen, oman tahtonsa ja arvojensa mukaan elävä ja amerikkalaisen vapauden mahdollisuuksia hyödyntävä yksilö lienee hyvä luonnehdinta myös tunnetusta "oman onnensa sepästä”. Riesmanin tutkimus kuitenkin osoitti 
aivan toista. Sisäistä vahvuuttaan Amerikan mies ei ollutkaan tehnyt itse, vaan oli omaksunut persoonallisuutensa "sisäistämällä ulkoisia sāäntöjä, moraalisia standardeja" ja tullut samalla muodostaneeksi itsestään vain ”jäykkien sääntöjen " ohjaaman, tahdonvoimaisen, viktoriaanisilla arvoilla varustetun yksilön. Ulkoa ohjautuva persoonallisuustyyppi, joka on samalla myös uudempi, puolestaan edustaa Riesmanin tutkimuksessa henkilöä, joka etsii vahvistusta itselleen toisten reaktioista "sopiakseen kuvioihin". Hän hakee itselleen ja teoilleen toisten hyväksyntää ja pyrkii toimimaan odotusten mukaisesti, hän saa "motiivinsa ja suuntansa toisilta" .

En tiedä, kuinka suuri merkitys David Riesmanin tutkimuksella on ollut itseohjautuvuuden käsitteeseen, mutta kasvatustieteellisessä keskustelussa ulkoaohjautuvuus on muodostunut itsestään selvästi itseohjautuvuuden vastinpariksi. Kukapa nyt haluaisi pitkän itseohjautuvuuskeskustelun jälkeen ainakaan aikuiskoulutusmaailmassa luokitella itseään ulkoa ohjautuvaksi? Näin kuitenkin on Riesmanin mukaan käynyt. Tälle on myös tuossa edellä esitetyssä merkityksessä hyvät perustelut monista eri syistä. Viittaan tässä vain lyhyesti kulttuurisosiologi Douglas Kellnerin toteamukseen, että nykyinen moderni entisestään vahvistaa sitä suuntaa, jossa ulkoiset ja toisista ohjautumisen piirteet lisääntyvät - identiteettejä on tarjolla paljon ja toisten kanssa toimiessa täytyy tuntea myös muita voidakseen paikantaa itsensä ja tulla itsekin paikannetuksi joksikin.

$\mathrm{K}^{2}$ asvatustieteellisessä ja erityisesti aikuiskasvaksen keskustelussa ja tutkimuksessa on mielletty itseohjautuvuuteen liittyviksi kysymyksiksi esimerkiksi opiskelumotivaatio. Kun oppivelvollisuus on suoritettu eikä varsinaista pakkoa opiskeluun ole olemassa, mistä nousee opiskelun mieli ja mikä panee aikuisen lähtemään koulutielle - 50-luvulla ei ollut mitenkään itsestään selvää, että aikuinen jostakin syystä oli motivoitunut opiskelemaan. Opiskelun aloittaminen kuitenkin ilmensi vahvaa itseohjautuvuutta, etenkin jos se suuntautui yksilöllisiin opintoihin eikä liittynyt johonkin muuhun harraste- tai kulttuuritoimintaan. Motivaatioon liittyy myös vastuu omasta oppimisesta, mikä korostuu silloin, kun opiskelija lähtee opiskelemaan yksilöllistä ohjelmaa niin, että hän itse myös suunnittelee sen ja suorittaa opiskelunsa pääasiassa muodollisen koulutusorganisaation ulkopuolella. Joissakin käsityksissä on puolestaan nähty jo varhain - Allen Tough 1960-luvulla - oppijan nousevan omaksi opettajakseen. Kolmantena esimerkkinä aikuisen oppijan itseohjautuvuudesta koulutustutkimuksessa voidaan ottaa esille Stephen Brookfieldin varhempi käsite itseohjautuvasta oppimisesta, jolla tarkoitetaan ulkoisesta ohjauksesta ja institutionaalisesta vahvistamisesta riippumatonta opiskelua.

Kun kasvatustieteiden antaman itseohjautuvuuskäsityksen mielle- tai arkimerkitystä lähdetään hakemaan edellä mainitulta pohjalta, edustaa se selkeästi sellaista kuvaa itseohjautuvasta opiskelijasta, joka on jättänyt jopa organisoidut oppimistilaisuudet taakseen ja toimii lähinnä Ivan Illichin kouluttoman yhteiskunnan idean mukaisesti. Todennäköisesti Illichin kuvaama tilanne, jossa jokaisesta kadunkulmasta löytyy jokin oppimisen paikka, on edelleen vain ideaali ellei haluta ottaa tosissaan sitä, että jokaisesta kadunkulmasta saattaa todella putkahtaa esille jotakin opittavaa.

Varsinaisen itseohjautuvuuspankin kuitenkin käytännössä räjäytti Malcom Knowles. Knowlesin tunnetuimmaksi noussut löydös on ollut jako lapsen riippuvuuteen ja aikuisen itseohjautuvuusvalmiuteen. Sillä perusteltiin samalla jako pedagogiaan ja andragogiaan, lasten kasvatukseen ja aikuisten oppimisen ohjaamiseen. Tämä 1980luvulla Suomeenkin rantautunut käsitys aikuis- 
kasvatuksen erityisyydestä, on myös muualla luonut pohjan katsella aikuiskoulutusta omasta kouluja lapsipedagogiikasta itsenäisenä ja itsenäistyvänä haaranaan. Voidaan hyvinkin arvioida, että itseohjautuvuus on ollut tavaramerkki, jolla aikuiskasvatus on noussut omaan arvoonsa. Itseohjautuvuuden käsitteellä on perusteltu aikuiskasvatuksen erillisyys muusta kasvatustieteestä ja aikuiskasvatus on pitkälti tämän käsitteen valossa ja varjossa alkanut myös elää omaa uutta - ja kieltämättä varsin rikasta elämäänsä.

$\mathrm{E}$ käy tässä läpi KNowLESIN tunnettua jaotteua lasten ja aikuisten eroista. Totean kuitenkin sen, että käsityksessä on pyritty perustelemaan sekä kehityspsykologiaan että ihmisen sosiaaliseen kasvuun liittyvin lainalaisuuksin sellaista humanistista ihmiskuvaa, jossa yksilö vähitellen kasvaa yksilönä itsestään ja omasta oppimisestaan vastuulliseksi. Humanistisen käsityksen valossa voidaankin Jukka Koron mukaan todeta jokaisen aikuisen olevan itseohjautuva ja tekevän matkaansa kohti omaa itseään ja täydellistymistään.

Itseohjautuvuuden paikka tuli siis sijoitetuksi yhtäältä yksilöön, itseohjautuvuus alkoi tulla kiinnostuksen kohteeksi juuri oppijan itseohjautuvuuden tilana. Oppilaitoksissa voitaisiin siis hyvin olettaa, että aikuinen on siirtynyt jo ennen opiskelunsa aloittamista riippuvuuden tilasta itseohjautuvuuden suuntaan silloin, kun opiskelija on vapaasta tahdostaan aloittanut opintonsa. Tai hänen olisi ainakin pitänyt jo siirtyä sellaiseen autonomian ja itsesäätelyn tilaan, jossa hän tajuaisi ottaa vastuun itsestään myös käytännön toimijana.

Kuitenkin aika pian alettiin havaita, etteivät aikuiset olekaan itsestään selvästi opinnoissaan itseohjautuvia ja poikkeavat paljonkin toisistaan. Selitystä opinnoissa etenemiselle ja oppimiselle oli helppo lähteä hakemaan juuri yksilöllisistä ominaisuuksista ja piirteistä, joiden katsottiin kuvaamaan itseohjautuvuusvalmiutta. Meilläkin runsaassa käytössä kulunut, 1970-luvun loppupuolelta peräisin oleva LuCy GuglieLminon itseohjautuvuusvalmiutta mittaava kysymyspatteristo on sekä tuonut paljon numerotietoja opiske- lijoiden keskinäisistä eroista ja voimakkaasti ollut aikuiskoulutuksen käytännön tasolla vahvistamassa näkemystä opiskelijoiden eritasoista valmiuksista. On tietenkin luonnollista, että mittarit tuottavat tuloksiksi erilaisia valmiuksia, koska ihmiset ovat erilaisia. Ongelma ei olekaan tässä asiassa, vaan siinä, että mittareiden käyttö on vienyt vahvasti käsityksiin, että itseohjautuvuus sijoittuu jotenkin yksinomaan yksilön sisään, ainoastaan hänen ominaisuuksikseen.

un tehdään arviointia siitä, miten tutkimusXieto on kohdellut itseohjautuvuutta, voidaan todeta, että humanistisen ihmiskäsityksen perusarvot on varsin nopeasti käännetty empiirisen tutkimuksen asetelmaksi, jossa erilaisella tilastollisella mittaamisella on korvattu ymmärtävä, ihmisen toimintaa tulkitseva näkökulma. On käynyt myös niin, että tämä tutkimussuunta on johtanut itseohjautuvuuden käytännöstä irralliseen ja samalla yhä pienempiin ja pienempiin abstrakteihin yksiköihin, joilla ei välttämättä ole enää paljonkaan tekemistä itse alkuperäisen tutkimuskohteen kanssa.

Toki tutkimuksissa itseohjautuvuutta on sijoitettu todellisiin koulutuksellisiin konteksteihin ja myös Suomessa on käyty laadukasta keskustelua käsitteeseen liittyvistä löydöksistä. Tällaisina voi mainita $\mathrm{mm}$. havainnot itseohjautuvuuden ja -valmiuden voimakkaista korrelaatioista yksilön minäkäsitykseen, itseluottamukseen, sosiokulttuuriseen taustaan. Kuitenkin esimerkiksi autonomia-käsitteeseen läheisesti kytketty systeeminen itsesäätelyn psykologisointi on edelleen keskusteluissa vahvasti mukana, ja pitää itseohjautuvuutta vankasti yksilön sisällä.

Itseohjautuvuus ei ole absoluuttinen ja itsenäinen kategoria, vaan käsite, jonka avulla voidaan edelleen käydä keskustelua koulutuksen ja opetuksen peruskysymyksistä, vaikkapa 80-luvulla voimissaan olleesta tasa-arvokysymyksestä tai koulutuksen syvemmistä tehtävistä ja vaikutuksista persoonallisuuden kaikinpuolisessa kehittämisessä. Käytäntöön vietynä esimerkiksi ammatilliselle aikuiskoulutukselle viesti on ollut selkeästi se, että kaikilla ei ole suoraa tietä vaativien ammatillisten pätevyyksien saavuttamiseen 
ilman yleissivistävien opiskeluvalmiuksien kehittämistä. Opiskelijasta ei tule itseohjautuvaa oppijaa tai työntekijää ilman vahvaa orientaatiota uusiin oppimis- ja työympäristöihin.

Cuomalaisessa keskustelussa jo varsin varhain toi Nuha Varila esille myös toisen näkökulman itseohjautuvuuteen, jossa käsite määritellään - edellisen oppijan tilanäkemyksen ohella - oppimisprosessin ominaisuudeksi, itseohjatuksi oppimiseksi tai opiskeluksi. Itseohjatussa oppimisessa oppijalla on vastuu huolehtia niin opintojen käytännöllisestä etenemisestä ja järjestelyistä kuin myös oppimisensa mentaalisesta ja reflektiivisestä puolesta. Jos oppijan tilaa käsitellään ensisijaisesti psykologisten teorioiden näkökulmasta, on itseohjattu prosessi puolestaan ensisijaisesti didaktiikan asia. Tämä merkitsi väistämättä myös oppijakeskeisyyden korostamista ja opiskelijan nostamista asemaan, joka aikaisemmin kuului opettajalle tai kouluttajille.

Yksinkertaisesti voidaan sanoa didaktisten elementtien ja koko prosessin siirtyvän itseohjatussa oppimisessa opiskelijan käytettävissä olevaksi resurssiksi, jota hän itse ohjaa. Opettaja entisenä didaktisena subjektina siirtyy syrjään, ja hyvinkin voidaan ymmärtää, että opiskelija ottaa itselleen itsensä opettajan tai autodidaktikon roolin. Jos tilanteeseen hakee vertausta vallan kolmijako-opista, jossa lainsäädäntövalta eli opiskelun suunnittelu, toimeenpanovalta eli toteutus ja tuomiovalta eli arviointi olivat ennen yksinomaan opettajan käsissä, olisi oppija tässä prosessissa nyt vastaavassa suvereenissa roolissa.

\section{Aikuiskoulutuskäytäntö : opetuksen oheneminen}

Aikuiskoulutuskäytännössä edellä mainitut kaksi käsitettä on sittemmin otettu luovaan käyttöön. On otaksuttu, että opiskelija on itseohjautuva ja niinpä rakennetaan sellaisia oppimiskonteksteja, joissa opiskelu perustuu itseohjatulle opiskelulle. Poikkeuksetta otollisimpana itseohjautuvan tai itseohjatun oppimisen ympäristönä pidetään erilaista monimuoto-opiskelua, joka muualla kulkee lähinnä etäopetuksen nimikkeen alla. Sa- nanmukaisesti opetus on siirtynyt kauemmaksi oppijasta ja oletetaan, että hän toteuttaa itsensä opettamista jollakin tavalla ja jossakin kaukana.

On monia syitä, jotka ovat johtaneet siihen kehityskulkuun, jossa itseohjautuvuuden idea otettiin erityisen voimakkaasti monimuoto-opetuksen ideologiseksi perusteluksi. Vähiten tähän ei vaikuttanut etenkään ammatillisen aikuiskoulutuksen puolella ja täydennyskoulutuksessa muuttunut lainsäädäntö, joka niin sanotusti vapautti koulutuksen markkinoille. Yhtälö oli helppo ratkaista; suurenevia aikuisopiskelijamääriä voitiin rahastaa vähemmillä panoksilla. Monimuoto-opetuksen toteutusten käsitettiin vaativan vähemmän resursseja kuin perinteisten ratkaisujen.

$\mathrm{M}$ onimuoto-opetus- ja itseohjautuvuusaikakausi, jonka alku voidaan sijoittaa 1980luvun lopulle, on johtanut monella tavalla aikuiskoulutuksen perusfunktion ohentumiseen. Opiskelijaa kohti annettavan opetuksen määrä, jota voidaan kutsua 'opetuksen ohentamiseksi' (termi Jari-Pekka Jyrkänne), on vähentynyt radikaalisti. Ensimmäisenä opetuksen ohentamisen muotona voidaan mainita yleensä pyrkimys aikuiskoulutuksessa nopeisiin ja lyhytkestoisiin tutkintoihin (esimerkiksi 1/2 nuorisoasteen suoritusajoista.) Toiseksi, opetusta annetaan tiiviinä teoreettisina paketteina, joiden perusteella opiskelijat tekevät etätehtäviä (esimerkiksi 1 viikko opetusta ja 1-3 viikkoa tehtäviä) tai työskentelevät 'itsenäisesti'; annettavan 'opin' määrä on laskenut huomattavasti. Kolmanneksi, opetus ammatillisessa koulutuksessa yleensä ohenee koulutuksen loppua kohti kuljettaessa ja siirryttäessä

On monia syitä kehityskul-

kuun, jossa itseohjautuvuuden idea otettiin erityisen voimakkaasti monimuoto-opetuksen ideologiseksi perusteluksi. Yksi niistä on tämä: suurenevia aikuisopiskelijamääriä voitiin rahastaa vähemmillä panoksilla. 
praktiseen vaiheeseen oletetaan opetusta tai muuta kontaktia tarvittavan hyvin vähän. Vastaavasti täydennyskoulutuksen puolella yleisesti käytössä olevat kehittämishankkeet tai lopputyöt jäävät tästä seuraten vaille ohjausta tai käsittelyä huolimatta siitä, että ne saattavat olla merkittävin vaihe opiskelua, johon oppijan omien ajatusten ja oppimistekojen odotetaan opetussuunnitelman mukaan tiivistyvän.

Opetuksen ohentaminen on johtanut siihen, että opiskelijat tapaavat opiskelijakumppaneitaan yhä vähemmän, jolloin myös 'reflektioajat ja -paikat' ovat vähentyneet. Paradoksaalisesti muutos on johtanut siihen, että koulutuksessa (tekninen) tieto kaadetaan entistä tiiviimpinä paketteina opiskelijoille, ja aineksen/materiaalin reflektio ja näin oman oppimisen (itse)arviointi jäävät sivuseikoiksi. Tästä näkökulmasta voidaan myös pohtia, kumpi näistä mahtaa olla koulutusinstituution ensisijainen laatutehtävä?

Aikuiskoulutuksen ja monimuotopedagogiikan eräs suurin kompastuskivi onkin ollut se, että itseohjautuvuus on väärällä tavalla käsitetty yksinohjautuvuudeksi. Opiskelu on muuttunut radikaalisti. Opiskelijan näkökulmasta katsoen vanhalla kouluoppimisen orientaatiolla ei voi edetä: itsenäisten tehtävien määrä on lisääntynyt, etäopiskelujaksot ovat pidentyneet ja muodostavat usein jo ajallisesti pisimmän vaiheen koko koulutuksessa, opiskelijoille on sälytetty suuri vastuu opiskeluympäristön määrittelystä, harjoittelupaikoista, itse opiskelun prosessista, opintosuoritusten keräämisestä ja niiden 'itsearvioinnista'.

Opetuksen ohentaminen on merkinnyt opiskelijan jättämistä suorittamaan koulutuksen vaatimusten kannalta hyvinkin merkittäviä tehtäviä yksin ilman että hän saa näille tekemisilleen sisällöllistä palautetta, oman henkilökohtaisen ammatillisen etenemisensä arvioinnista puhumattakaan. Tehtävät eivät jäsenny merkittäviksi opiskelumateriaaleiksi tai niitä ei ole aikaa tarkastella oppimistuotteina, jotka mahdollisesti kaipaavat jatkotyöskentelyä ja korjauksia. Usein tilanne on sellainen, että opiskelijan etätyöjaksoilla opettajat joutuvat tekemään varsinaista työtään eli 'an- tamaan opetusta' muussa koulutuksessa ja olemaan uusia koulutuksia ja suunnitelmia 'tuottavassa' työssä sen sijaan, että ohjaisivat opiskelijoiden oppimisprosesseja etätehtävissään tai työssäoppimisjaksoilla.

$\mathrm{H}$ aluan tuoda esille, että monimuoto-opiskelussa tai avointen oppimisympäristöjen ideoissa sinänsä ei ole mitään vikaa, vaan ne ovat olleet erittäin tervetulleita sekä murtamaan niitä opetuskäytäntöjä, jotka ovat perustuneet yksinomaan behavioristiselle näkemykselle opettamisesta että luomaan jälleen uusia käsityksiä oppimisesta. Monimuoto-opiskelu on muodoltaan erinomainen kokonaisuus, jossa opiskelija erilaisten, toisistaan poikkeavien toimintamuotojen kautta lähestyy opittavia asioita. Se mitä itseohjautuvuudelle on käynyt ja miten itseohjautuvuuden ideaa on käytetty, antaa kuitenkin aiheen suurelle kritiikille, kun ajatellaan aikuiskoulutuksen perustehtäviä. Kritiikkini tiivistyy tässä yhteydessä siihen, että itseohjautuvuus on viety yksinopiskeluksi ja yksinohjautumiseksi. Tällä kehityssuunnalla ei ole koulutukselta odotettavien tulosten ja laadun nostamisen kannalta enää mitään tekemistä.

Kun itseohjautuvuus ei ole yksinohjautuvuutta, voidaan päätellä, että itseohjautuvuuden tila erityisesti ammatillisessa aikuiskoulutuksessa kaventunut. Opiskelijalle tarjotaan vähemmän aikaa ja tilaa refleksiiviseen oppimiseen eli oppimiseen, jossa hän saa vuorovaikutuksen kautta itselleen aikaa ja huomiota arvioida itseään, kehittymistään ja suorituksiaan. Ei ole yllättävää, että aikuisten täydennyskoulutus- ja korkeakouluopintojen ja aikuisten ammatillisten opintojen ongelmat ovat johtaneet mm. suureen keskeyttäneiden määrään, opintojen viivästymisiin ja kritiikkiin tätä kehityssuuntaa vastaan.

\section{Mitä seurannut - muutama ongelma}

Otan tässä yhteydessä esille ongelman, josta on puhuttu vähän koulutuksen ohentamisen ja yksinopiskelun seurausten yhteydessä. Asia koskee kokonaisuutena koko aikuiskoulutuksen funktiota kansalaisten sivistymisen, kvalifioimisen ja 
itsensä kehittämispyrkimysten paikkana. Pitää todeta, että aikuiskoulutuskeskustelussa on varsin paljon pohdittu niitä tehtäviä, joilla se kytkeytyy muuttuvaan toimintaympäristöönsä. Itse instituutioiden käytännössä pedagoginen keskustelu on kuitenkin jäänyt useimmiten retoriikan tasolle arkea sävyttävän taloudellisen selviytymisen rinnalla. Tästä on hyvänä esimerkkinä, mutta vain jäävuoren huippuna, voimistunut huoli esimerkiksi aikuiskoulutuskeskusten toiminnan rahoituksesta. Näillä resurssien vähennyksillä kuitenkin aiheutetaan ennen näkemätön kuilu koulutusjärjestelmän sisälle.

1 970-luvulla ja vielä 80-luvun alkupuolella sekä yleinen koulutuspolitiikan että erityisesti aikuiskoulutuksen keskeinen tavoite johdettiin koulutuksellisen tasa-arvon pyrkimyksestä. Tuolloin pohdittiin ei vain mahdollisuuksien tasa-arvoa vaan myös tulosten tasa-arvoistamista. Aikuisten ja nuorten koulutuskuilun kurominen umpeen nähtiin erääksi keskeiseksi tavoitteeksi. Samoin aikuisten välisten koulutuserojen tasoittaminen niin, että koulutus tasaisi kaikkien valmiuksia hallita paremmin elämänsiirtymiä ja varsinkin tasoittaa mahdollisuuksia työmarkkinoilla. Sekä 70-luvun alun koulutuskomitea että aikuiskoulutuskomiteat näkivät tasa-arvovaatimuksen kumpuavan tuotannon ja siinä erityisesti teknologisen kehityksen edellyttämistä kaikkien kvalifikaatioita nostavista vaatimuksista. Jokainen voi miettiä, kuinka on käynyt ja käymässä.

Itseohjautuvuuden kääntyminen käytännössä yksinopiskeluksi on työelämän kvalifikaatiovaatimuksille täysin vastakkainen tendenssi. Puutun tähän vielä myöhemmin. Keskeinen kysymys onkin jälleen tasa-arvo silloin, kun ennustetaan työvoimapulaa ja nostetaan työvoimatarpeen ja tarjonnan kohtaamattomuus ongelmaksi. Jo tällöin vaaditaankin sitä, että koulutus tuottaa omalle toiminnalleen luontevaa outputia, itseohjautuvia ja kvalifikaatiotasoaan nostavia ei pelkästään työvoimavarantoaan säilyttäviä kansalaisia ja työntekijöitä. Lyhentyneet koulutukset tai koulutukset, joissa ihmiset voivat kerätä peräjälkeen satunnaisia koulutuspaketteja, eivät auta tässä tilanteessa sen paremmin kuin sekään, että kukin opiskelee itselleen omassa yksinäisyydessään ties minkälaisia pitkiäkin tutkintoja. Suuret opintojen keskeyttämismäärät, viivästymiset ja jopa haluttomuus aikuiskoulutukseen ovat hyviä empiirisen tutkimuksen kohteita - mistä kaikki tämä johtuukaan?

$\mathrm{K}$ oulutuksen keskeyttämistutkimuksissa on oikkeuksetta nostettu opiskelun institutionaalisen puolen merkitys olennaiseksi (Vincent Tinto). Aivan hyvin voidaankin tulkita, että opiskelija ei saa omalle itseohjautuvuudelleen eli tyypillisesti jo opintojen alussa itselleen sellaista refleksiivistä palautetta, joka luo edellytykset toimintaan sitoutumiselle, mikä puolestaan on edellytys oppimisprosessin myöhemmille vaiheille tai sykleille. Itseohjautuvuus vaatii aina responsia, itseohjautuvuus on vuorovaikutuksellinen suhde ja jos kukaan ei ole instituution puolelta vastaamassa opiskelijan itseohjautuvuusaloitteeseen tai -tarjoumaan, ja itseohjautuvuusyritykset jäävät vaille palautetta (aikaa, huomiota ja kunnioitusta), on opinnoista vetäytymisen kierre monelle viimeinen itsekunnioituksen keino.

Keskeyttämistilanteissa koulutusorganisaation olisikin käännyttävä katsomaan itseään peilistä: mikä meidän toiminnoissamme on korjattavaa niin, että opiskelijat kokisivat opiskeluorganisaation paikaksi, johon myös pystyvät sitoutumaan ja joka saa aikaan sellaisen opiskelun ilon ja positiivisen flow-ilmiön, että opiskelijasta on vaikea päästä eroon.

Kun vielä 70-luvulla koulutuksellisen tasa-arvopyrkimyksen toteuttamisen mahdottomuutta pyrittiin perustelemaan opiskelijoiden älykkyysosamäärien vaihteluilla, on tämän saman paikan vaivihkaa vallannut itseohjautuvuusvalmius. Itseohjautuvuus- ja ohjautumattomuus on alkanut jakaa ja valikoida aikuisopiskelussa menestyjiä ja

Itseohjautuvuuden kääntyminen käytännössä yksinopiskeluksi on työelämän kvalifikaatiovaatimuksille täysin vastakkainen tendenssi. 
menestymättömiä. Kukin on yksin omalla tasollaan ja itseohjausvalmiuksillaan oman onnensa seppä. Kun tiedämme työelämän ja talouden muodostavan yhä selkeämmin kuiluja eri ryhmien ja yksilöiden välille, täytyykö koulutuksen tehdä samoin ja vain seurata perässä?

$\mathrm{H}$ uomattava muutos on se, että koulutus on itse - eikä vasta työelämä koulutuksen jälkeen - alkanut identifioitua myös epäonnistumisen paikaksi ja koko järjestelmä on ottanut sellaisen valikointitehtävän, jota sillä ei ole aikaisemmin ollut; se tuottaa epätasa-arvoa kumuloivia tuloksia toimien itse myös syrjäytymisen tuottajana. Toki koulutus toimii ja on toiminut aina myös valikoinnin paikkana, jossa opiskelijat saavat numeroilla ja erilaisilla todistuksilla määritellyt identiteettinsä. Olennainen ero kuitenkin liittyy siihen, että aikuiskoulutuksessa epäonnistunut siirtyy yleensä entistä yksinäisemmin nuolemaan näppejään instituution ulkopuolelle opinnot keskeytettyään. Minäkuva saa uuden vahvistavan leiman, eikä aikuiskoulutusinstituutio voi onnitella itseään sen perusteella että opiskelija osasi viimeinkin itseohjautua sen ulkopuolelle. Keskeyttämiset tuskin ovat minkään oppilaitoksen toiminnan tavoitteena. Mitä enemmän tahatonta valikointia ja epäonnistumiskokemuksia tuotetaan, sitä vaikeammaksi myös käy se hakeva toiminta, jolla opiskelua pyritään uudelleen ulkoa käsin motivoimaan. Kuitenkin näin

Huomattava muutos on se, että koulutus itse - eikä vasta koulutuksen jälkeinen työelämä on alkanut identifioitua myös epäonnistumisen paikaksi ja koko järjestelmä on ottanut sellaisen valikointitehtävän, jota sillä ei ole aikaisemmin ollut; se tuottaa epätasa-arvoa kumuloivia tuloksia toimien itse myös syrjäytymisen tuottajana. on tapahtunut: erillisillä projektirahoituksilla pyritään jo nykyisin huolehtimaan tällaisesta toiminnasta. Tämän myötä on myös vaara, että tuotetaan entisestään epätasa-arvoa lisääviä koulutussaarekkeita, ellei kytkentä formaaleihin, tutkintoihin johtaviin koulutuksiin selkeiden polkujen ja pitkien kehittymisohjelmien muodossa toteudu.

\section{Miltä tulevaisuus näyttää?}

Onko aikuisopiskelun järjestelyissä mitään korjattavaa ja onko mitään syytä niiden muuttumiseen? Otan esille muutaman seikan, jotka mielestäni varsin yksinkertaisesti, mutta selkeästi viestivät, että itseohjautuvuus ajautuneena yksinohjautuvuudeksi tai käsitettynä opiskelijan ominaisuudeksi tulisi olla ohitse - yhtä hyvin kuin käsitys siitä, että voitaisiin muotoilla itseohjaavia oppimisprosesseja, joissa opiskelijan yksilöllisiä lähtökohtia ja minää toimijana ei tarvitse ottaa huomioon.

$\mathrm{M}$ erkitys, joka itseohjautuvuudelle annetaan, uleekin kääntää toisenlaiseksi kuin se mielleyhtymä, johon on totuttu. Kun puhutaan itseohjautuvasta oppijasta, tulee käsittää hänet sellaiseksi, joka tarvitsee ja myös hakee enemmän kontaktia. Kun suunnitellaan itseohjautuvuusideaan perustuvia opiskelukokonaisuuksia, tulee korostaa osallistumisen mahdollisuuksien lisäämistä. Kun puhutaan itseohjautuvuuden käyttämisestä didaktisten ratkaisujen taustaideana, tulee muotoilla osallistavia tekniikoita ja menetelmiä. Kun puhutaan itseohjautuvan oppimisen rahoituksesta, tulee varautua suurempiin kustannuksiin kuin tavanomaisen opetuksen puitteissa. Etenkin kun tavoitteena on samanaikaisesti tukea itseohjautuvuutta, edellä mainitut seikat korostuvat.

$\mathrm{E}$ NSINNÄKIN työelämän koulutukselta odottamat ulokset ovat täysin vastakkaisia sille, mihin yksinopiskelu johtaa. Vuorovaikutus-, kommunikaatio-, esiintymis- ja itsensä ilmaisun taidot ovat avain, paitsi opiskelussa, myös nykyisessä työelämässä työmarkkinakvalifikaatioista puhumattakaan. Kun fyysiset suoritusvaatimukset ovat jo aikoja sitten ammatillisen konkreetin toimin- 
nan tasolla ja pedagogiikassa kognitiivisen käänteen myötä korvautuneet vaatimuksilla ajatella ja tarkastella asioita älyllisesti, muuttaa skeemoja, on nykyajan työelämä vaatimassa sellaista työntekijää, joka toimii ennen kaikkea erilaisten symbolien ja merkitysten antamisen kielellisessä ja toiminnallisessa verkostossa. Verkostoituneessa toiminnassa itsensä ymmärtäminen ja ymmärrettäväksi tekeminen on myös yksilöllisen toiminnan A ja O. Kun perusehto on kuitenkin pystyvyys toimia yhdessä ja tuottaa yhteisiä produkteja, oppiminen saa entistä selkeämmän yhteistoiminnallisen luonteen.

$\mathrm{T}$ OISEKSI - onkin melkein paradoksi, että humanistisesta puheesta alkanut itseohjautuvuuskeskustelu on saamassa vakavimman käytännöllisen ratkaisijansa opetusteknologian kehittämisen kautta. Suomessa tällaisena käänteenä voidaan pitää 1997 Lehtisen toimittamaa verkkopedagogiikka-kirjaa. Teoksen yleisviesti on selkeästi se, että verkkopedagogiikka luo pohjan ja kytkeytymispinnan itseohjautuvalle ja itseohjatulle yksilölliselle oppimiselle, mikäli sen sosiaalinen verkko toimii. Itseohjautuvuuden kehittyminen tapahtuu osallistamisen muotoja ja välineitä kehittämällä, mikä merkitsee pedagogisen ajattelun priorisointia oppimisalustojen käytön suunnittelussa, rakentamisessa ja käytössä. Sama idea jatkuu Janne Matikaisen ja Jyri Mannisen toimittamassa Aikuiskoulutus verkossa teoksessa: avoimet oppimisympäristöt ja itseohjattu opiskelu vaativatkin ensisijassa vaativan ohjauksen.

$\mathrm{K}$ OLMAS merkittävä yksinopiskelua voimakkaasti ritikoiva haaste tulee kognitiivisen psykologian puolelta. Ihmisen älykäs toiminta on sen mukaan jossakin muualla kuin yksilön päässä. Se sijaitsee, jos sille jokin paikka halutaan osoittaa, pikemminkin ihmisten välisissä toiminnoissa. Tai kuten amerikkalainen psykologi ja kasvatuksen tutkija Jerome Bruner asian tiivistää: "yksilön älykäs toiminta ei ole koskaan "yksinäistä" (solo). Sitä ei voida ymmärtää ottamatta huomioon hänen lähdekirjojaan, muistiinpanojaan, tietokoneohjelmiaan ja, ennen kaikkea sitä ystävien, työtovereiden ja ohjaajien verkkoa, jolta yksilö saa tukea ja neuvoja."
Kognitiivisen psykologian näkemys ns. hajautetusta kognitiosta, jota esimerkiksi Kirsti Lonka ja Kai Hakkarainen ovat meillä tuoneet esille, vie koko pedagogisen ajattelun ja sen myötä uuden oppimisen käsityksiin, joiden myötä oppiminen muodostuu tiedonrakenteluksi toisten kanssa. Tieto on ihmisten välissä ja konstruoidaan ennen kaikkea yhteisten toimintojen kautta. Sama ajatus on toki sisältynyt jo kauan sosiaalipsykologian klassikoiden teksteihin, mutta voidaan arvioida, että hajautetun kognition ja asiantuntijuuden käsitteiden kautta malli on lyömässä itseään läpi myös käytännön koulutusajattelussa.

Vastausta oppimiselle ei haetakaan enää puhtaan sisäisen ajattelun kehittymisestä tai suoraan reflektiosta, vaan siitä, miten parhaiten konstruoidaan tuolle ajattelullekin otollisia olosuhteita (habitaatteja). Kysymykseen tulevat tätäkin kautta sellaiset tiedonrakentelun muodot, joiden kautta ihmiset saatetaan yhteen - mikä olisikaan parempi orientaatio koko aikuiskoulutukselle tai itseohjautuvuuden käsitteelle. Tällöin samaan seikkaan yhdistyy myös käsitys arkipäivän oppimisesta eri muotoineen. Siitä seuraa myös näkemys, että ihmiset ovat joka tapauksessa "jo jollakin tavalla" itseohjautumassa myös opiskelemissaan asioissa. Koulutuksen ensisijainen tehtävä on antaa vain foorumi myös sen selvittämiseksi, miten he ovat "jo tekemässä" sitä, ja miten he voivat viedä yhdessä omaa ohjautuvuuttaan eteenpäin.

Pedagogiikassa ei tarvitse enää simuloida niinkään aivoissa tapahtuvaa (oppimis)käännettä, vaan huomio kohdistetaan niihin tekijöihin, joilla oppijat järjestetään itse ratkaisemaan ja rakentamaan ja arvioimaan oppimistaan. Vaikka ajattelun muutospyrkimyskin saattaa olla piilo-opetussuunnitelmana, kohdistuu huomio nyt niihin ulkoisiin järjestelyihin, joiden kautta "sisäiset kognitiot" saatetaan yhteen, keskustelemaan ja toimimaan toistensa kanssa. Zygmunt Bauman on todennut, että vasta toisten erilaiset ajatukset ja näkemykset "pamauttavat tajunnan liikkeelle”. Ne voivat pamauttaa tietenkin myös defenssit liikkeelle yhtä hyvin, ja siksi oppimistilaisuudet vaativatkin uusia ohjauksen muotoja, joissa ollaan vapautuneita suorasta oppimiseen "pakot- 
tavasta opettamisesta”, mutta joissa keskinäinen tiedonrakentelu on turvallista.

$\mathrm{N}$ ELJÄNTENÄ itseohjautuvuuskäsitystä muuttavana seikkana en malta olla ottamatta esille eettistä kysymystä, jonka kautta yksinopiskelu on erityisen ongelmallinen. Kysymys on siitä, kuinka perustavanlaatuisesti ja syvästi itseohjautuvuus halutaan käsittää ja mihin sen toivotaan ulottuvan. Tekniset psyko- tai sosiometriset mittaukset eivät yllä vastauksillaan tuottamaan itseohjautuvuutta. Ihmisen identiteetin kehittymisen kaaressa, elämänkulussa ja siirtymissä ainoastaan reaaliset ja konkreettiset toiset voivat toimia tuon identiteetin muodostuksen ja myös merkitysperspektiivien luonnollisimpina ja tärkeimpinä avaajina. Uudet merkitykset ja esimerkiksi merkittävät oppimistapahtumat kytkeytyvät aina "toisten" alkuun saattamiin virikkeisiin tai suoraan tällaisiin kohtaamisiin "merkittävien toisten" kanssa. Runsaaksi käynyt kasvoton informaatio, data ja jopa tieto saavat merkityksen ja kasvot toisilta eläviltä. Semioottisessa tulkinnassa toinen ja tarkemmin "sinä" myös edustaa aina tulevaa. Tässä yhteydessä kannattaa perehtyä Emmanuel Levinasin etiikan filosofiaan, jossa myös merkityksellinen aika muodostuu suhteesta toisiin.

Paitsi, että merkitykset ja merkitysperspektiivit avautuvat dialogisissa suhteissa, kommunikaation yhteydessä, toinen ja toiset toimivat aina solidaarisuuden ja eettisyyden elävinä takeina. Tämä ei tarkoita paluuta sellaiseen ulkoaohjautuvuuteen, jonka Riesman näki toteutuvan "ulkoa sisään"-periaatteella, vaan sellaista toisten kanssa työskentelyä, joka on omiaan synnyttämään demokraattisuutta ja vastuuta myös muista. Samalla myös itseohjautuvuudessa tärkeä vastuun käsite muuttuu ensisijaisesti koskettamaan vastuuta toisesta. Omiin saavutuksiin ja valtapyrkimyksiin yhdistyvän autonomian käsitteen sijaan Marcie Boucouvalasin mukaan ihmisen kasvu ja kehitys tulisi nähdä paremminkin homonymian käsitteen kautta, jossa minuuden kasvua motivoi osallistuminen ja yksilöllisen minän ulkopuolinen toiminta. Oma ainutlaatuisuus tulee tunnistetuksi ja yksilöllisiä ominaisuuksia voi kehittää vasta kuuluen mielekkääseen ja merkitykselliseen elämiskokonaisuuteen.
$\mathrm{J}$ ACK Mezirowin käsitystä itseohjautuvuudesta, mikä on Suomessa tullut tunnetuksi lähinnä Leena Ahteenmäki-Pelkosen kirjoitusten kautta, pidetään yksilölähtöisenä siksi, että siinä lähtökohtana on yksilöllinen oppijan reflektio ja ylipäänsä reflektion käsite. Äärimmillään koulutus ei ole aikuiskoulutusta ellei se päädy oppijan itsereflektioon ja oman merkitysperspektiivin kriittiseen arviointiin. Olennaista on kuitenkin se, että tuossa käsityksessä itseohjautuvuutta ei viedä oppijan ominaisuudeksi, vaan se määritellään mahdollisuuksiksi "osallistua kriittiseen diskurssiin”. Samaa käsitystä edustavat selkeästi myös aikuiskoulutustutkijat ja -kriitikot Michael Collins ja Stephen Brookfield, joiden mukaan osallistuminen omista lähtökohdista antaa mahdollisuuden tuoda esille juuri kriittisiä kysymyksiä, mikä tulee mahdolliseksi vasta dialogisten käytäntöjen kautta.

Toki ihminen ja oppija kommunikoi kaikenlaisen materiaalin kanssa, jonka hän saa oppimistarkoituksessa käsiinsä. Tämän pystyy tekemään informaalisti jopa ilman koulutusta tai opetuksia - ja näinhän useimmiten tapahtuukin. Mikä jää sitten aikuiskoulutuksen institutionaalisen ja formaalin puolen hoidettavaksi? Edellä esitetyn perusteella ei nähtävästi ole mitään niin suurta tehtävää kuin saattaa oppijat vuorovaikutukseen ja keskusteluihin omasta oppimisestaan ja omista tulkinnoistaan olipa kysymys mistä hyvänsä opittavasta kohteesta. Vasta osallistamisen muotojen kehittämisen kautta voidaan myös legitimoida formaalin koulutusjärjestelmän toimintoja. Kun itseohjautuvuutta ei voi opettaa ulkoa sisään behavioristisella periaatteella, on käännettävä aina joka käänteessä katse oppijaan. Miten hän on "jo" ajattelemassa tai toimimassa opittavan asian suhteen. Tämä merkitsee sellaisten oppimisareenoiden luomista, jossa oppija saa sekä kiinni omasta merkitysperspektiivistään että samalla reflektoi myös omaa itseohjautuvuuttaan. Ei itse asiassa tarvita muuta kuin dialogisia rakenteita, koska dialogi itsessään pakottaa "miettimään omia ajatuksia".

Sessa yksinomaan opetus ei ole aina oikea keino luoda itseohjautuvuuden kannalta otolli- 
sia didaktisia tiloja. Siihen soveltuva työmuoto ja toimintatapa on ohjaus, jota ei tule käsittää pelkästään oppimisen tukimuodoksi tai ikään kuin viimeiseksi oljenkorreksi, jos opetuksella tai itseopiskelulla ei päästä eteenpäin. Vielä 90luvun alkupuolella merkittävä tutoroinnin asiantuntija kirjoitti, että ohjaajan toiminnan tavoite on tehdä itsensä prosessin kuluessa tarpeettomaksi. Vaativassa aikuiskoulutuksessa tällaista tavoitetta ei voi pitää päämääränä siksi, että ohjaus ei ole ongelmallisten tilanteiden selvittelyä tai tulipalon sammuttamista tai muuten opetusta vähempiarvoinen asia, joka voidaan jättää taakse, kun asiat ensin saadaan sujumaan ikään kuin itsestään. On nähty, että asiat eivät suju yksin eivätkä itsestään. Haluaisin nähdä, miten ne muuten kuin ohjauksella - saadaan sujumaan itsestään.

\section{Kirjallisuutta}

AHTEENMÄKI-PELKONEN L (1997): Kriittinen näkemys itseohjautuvuudesta. Systemaattinen analyysi Jack Mezirowin itseohjautuvuuskäsityksistä. HY, Kasvatustieteen laitoksen tutkimuksia 157.

BAUMAN Z (1996): Postmodernin lumo. Tampere: Vastapaino.

Boucouvalas M (1988): An analysis and critique of the concept of self in self-directed learning. Teoksessa Zukas M (ed.): Papers from the transatlantic dialogue: Scutrea 1988. University of Leeds.

BROOKFIELD S (1982): Independent adult learning. Nottingham: University of Nottingham, Department of Adult Education.

BROOKFIELD S (1986): Understanding and facilitating adult learning: a comprehensive analysis of principles and effective practices. Milton Keynes: Open University Press.

BROOKFIELD S (1995): Kriittiset tapahtumat oppijoiden olettamusten tutkimisessa. Teoksessa Mezirow et al.: Uudistava oppiminen. Kriittinen reflektio aikuiskoulutuksessa. Helsinki: Painotalo Miktor.

BRUNER J (1990): Acts of meaning. Cambridge: Harvard University Press.

Collins M (1998): Critical crosscurrents in education. Malabar, Florida.

GUGLIELMINO L (1977): Development of the self-directed learning readiness scale. University of Georgia. Unpublished doctoral dissertation.

HAKKARAINEN K (1997): Verkostopohjaiset oppimisympäristöt ja kognitio. Teoksessa Lehtinen E (toim.): Verkkopedagogiikka. Edita. Helsinki.

HAKKARAINEN K, Lonka K, Lipponen L (1999): Tutkiva oppiminen. WSOY.

HAKKARAINEN K (2000): Oppiminen osallistumisen prosessina. Aikuiskasvatus 2/2000.

ILLICH I (1972): Kouluttomaan yhteiskuntaan. Helsin- ki, Otava.

JOKINEN R (1997): Tietämättömyyden etiikka. Emmanuel Levinas modernin subjektin tuolla puolen. SoPhi. Yhteiskuntatieteiden, valtio-opin ja filosofian julkaisuja 15. Jyväskylän yliopisto.

JYRKÄNNE J-P (1992): Ammatillinen aikuiskoulutus ja työelämä - näkökulmia työn ja koulutuksen suhteeseen. Aikuiskasvatus 3/1992.

KELLNER D (1992): Popular cultures and the construction of postmodern identities. Teoksessa Lash S \& Friedman J (eds): Modernity \& Identity. Blackwell Oxford-Cambridge.

KNOWLES M (1975): Self-directed learning: a guide for learners and teachers. New York: Association Press.

KNOWLES M (1980): The modern practise of adult education: from pedagogy to andragogy. Chicago: Follet.

KORO J (1993a): Aikuinen oman oppimisensa ohjaajana. Jyväskylä studies in education, psychology and social research 98 .

KORO J (1993b): Itseohjattu oppiminen - aikuiskoulutuksen tavoite vai väline. Kirjassa Aikuisten oppimisen uudet muodot. Kansanvalistusseura ja Aikuiskasvatuksen tutkimusseura. Jyväskylä: Gummerus.

LEHTINEN E (toim.) (1997): Verkkopedagogiikka. Edita. Helsinki.

LEVINAS E (1996): Etiikka ja äärettömyys. Keskusteluja Philippe Nemon kanssa. Suomennos ja esipuhe Antti Pönni. Gaudeamus, Tampere.

LONKA K, Hakkarainen K (2000): Oppiminen vuonna 2020?. Psykologia 2/2000.

Mezirow J (1981): A critical theory of adult learning and education. Adult education 32, 1.

MEZIROW J (1995): Kriittinen reflektio uudistavan oppimisen käynnistäjänä. Teoksessa Mezirow et al.: Uudistava oppiminen. Kriittinen reflektio aikuiskoulutuksessa. Helsinki: Painotalo Miktor.

PASANEN H (1998): Refleksiivisen itseohjautuvuuskäsityksen hahmotusta. Teoksessa Manninen J (toim.): Aikuiskoulutus modernin murroksessa. Helsingin yliopiston kasvatustieteen laitoksen tutkimuksia 158.

RIESMAN D (1950): The Lonely Crowd: a study of the changing american character. New Haven.

TINTO V (1975): Dropout from higher education. Review of Educational research 45 (1).

TOUGH A (1966): The assistance obtained by adult self-teachers. Adult Education Quarterly, 17 (autumn).

VARILA J (1990): Itseohjautuvan oppimisen käsitteellistä ja empiiristä tarkastelua. Helsingin yliopiston LTKK tutkimuksia 2.

\section{Muut lähteet}

Tilastotietoja aikuiskoulutuksessa suoritetuista opinnoista eri tietokannoista $(\mathrm{mm}$. KOTA, oppilaitokset).

Haastattelut ja keskustelut opettajien, ohjaajien ja suunnittelijoiden kanssa.

Omat kokemukset toteuttajana ja osallistujana.

Heikki Pasanen piti samansisältöisen puheenvuoron Ohjauksen ulottuvuudet -seminaarissa Kaapelitehtaalla 12.10.2000. 